doentes é normalmente complexa e requer procedimentos conservadores, em detrimento de procedimentos invasivos, que devem ser evitados. Em destaque, medidas preventivas de saúde oral com motivação da higiene do doente, uso de colutórios contendo clorexidina e remoção de placa bacteriana. Os procedimentos invasivos, quando urgentes, devem ser realizados em meio intra-hospitalar, com estudo analítico e tipagem sanguínea do doente, caso seja necessário realizar transfusão sanguínea.

http://doi.org/10.24873/j.rpemd.2020.12.769

\section{\#047 Sialometaplasia Necrosante: Uma Lesão Benigna Sugestiva de Malignidade}

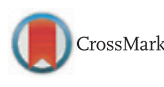

Mariana Magalhães Maia*, Cristina Moreira, Rita Martins, Pedro Cabeça Santos, Nuno Gil, Francisco Azevedo Coutinho

Centro Hospitalar de Vila Nova de Gaia; Centro Hospitalar Universitário de São João

Introdução: A sialometaplasia necrosante (SMN) é uma doença incomum, benigna, inflamatória e necrosante de glândulas salivares menores. A etiologia parece ser uma necrose isquémica e caracteriza-se, numa fase inicial, pela desintegração das células acinares por necrose, surgindo posteriormente uma metaplasia escamosa e reação fibrosa. As lesões podem aparecer sob a forma de nódulos ou evoluir para ulceração do epitélio adjacente, sendo esta a forma que mais frequentemente motiva a observação clínica. Descrição do caso clínico: Género feminino, 22 anos, raça negra, praticante de culturismo com antecedentes patológicos de perturbação alimentar. Sem hábitos tabágicos, etílicos, consumo de estupefacientes ou anabolisantes. Recorreu ao Serviço de Urgência de Estomatologia devido ao surgimento de uma 'bolha' no palato, com cerca de três semanas de evolução, com aumento progressivo do seu volume e ulceração ao final de duas semanas. Concomitantemente referia tumefação bilateral da face de início insidioso há mais de um mês. À observação objetivou-se tumefação bilateral e simétrica das glândulas parótidas e submandibulares, indolores à palpação. No exame intraoral identificou-se uma lesão ulcerada no terço posterior do hemipalato duro esquerdo, com cerca de $1,5 \mathrm{~cm}$ de maior eixo, crateriforme com bordos irregulares e associada a dor à palpação. A doente foi submetida a biópsia incisional da lesão, cujo estudo anatomopatológico revelou tratar-se de sialometaplasia necrosante. Realizou ainda uma biópsia de glândulas salivares menores e avaliação analítica sorológica que não revelaram alterações. Discussão e conclusões: A etiologia da SMN permanece incerta, existindo fatores predisponentes, tais como: fatores traumáticos, anestesias locais, próteses mal adaptadas, infeções do trato respiratório superior, tumores adjacentes, cirurgias prévias e distúrbios alimentares. No entanto, alguns casos ocorrem sem qualquer fator predisponente conhecido. O facto de mimetizar uma patologia maligna, tanto clínica como microscopicamente pode originar erros diagnósticos, particularmente graves pelo risco de motivar mutilações cirúrgicas desnecessárias. O prognóstico é muito favorável e o tratamento é sintomático, uma vez que a doença é autolimitada e involui espontaneamente sem deixar sequelas. Neste caso em particular a etiologia mais provável é o distúrbio alimentar, uma vez que tanto a SMN como a sialoadenose podem ser explicadas por esta alteração.

http://doi.org/10.24873/j.rpemd.2020.12.770

\section{\#048 Infiltração maligna da gengiva e palato por entidade rara}

Cristina Moreira*, Carina Ramos, Mariana Magalhães Maia, Rita Martins, Teresa Corrales, Sónia Viegas

Centro Hospitalar de Vila Nova de Gaia/Espinho; Centro Hospitalar e Universitário de São João

Introdução: A Neoplasia de Células Blásticas Plasmocitóides Dendríticas (NCBPD) é um tipo raro e agressivo de linfoma com um número aproximado de 100 casos reportados em todo o mundo. Foi recentemente reclassificada como uma entidade clínica própria em 2016 [Revisão da Organização Mundial de Saúde (OMS)] e a sua etiologia mantém-se desconhecida. Trata-se de uma patologia que pode ocorrer em qualquer idade embora com predileção para o idoso, sendo a idade mediana de diagnóstico os 67 anos. Clinicamente caracteriza-se por manifestações cutâneas (placas ou nódulos cuja cor varia de vermelho a púrpura) bem como disseminação tipo leucemia envolvendo os gânglios linfáticos e o sangue periférico. Em geral a NCBPD refratária/recidivante associa-se a mau prognóstico com opções terapêuticas limitadas. Descrição do caso clínico: Doente do sexo masculino, 73 anos, referenciado à Consulta de Estomatologia pela Hemato-Oncologia. Apresentava queixas de hipertrofia gengival, gengivorragia e desconforto local dificultando a alimentação, com 4 meses de evolução. Nove meses antes havia sido diagnosticado com NCBPD no contexto de astenia, anorexia, perda ponderal e aparecimento de placas cutâneas acastanhadas na cabeça e tórax. Cumpriu esquema de quimioterapia com remissão completa. Ao exame objetivo destacava-se hipertrofia gengival difusa com coloração violácea escura, bem como coloração violácea heterogénea da quase totalidade do palato. Procedeu-se a biópsia incisional da gengiva cuja histologia foi compatível com recidiva de NCBPD. Após discussão multidisciplinar foi proposto um diferente regime de quimioterapia e controlo hemorrágico oral, focado na eliminação do biofilme e medidas hemostáticas locais. Discussão e conclusões: A NCBPD é uma entidade rara $(0.44 \%$ das neoplasias malignas hematológicas). Caracteriza-se por envolvimento cutâneo predominante com subsequente ou simultânea extensão à medula óssea e sangue periférico. As mucosas, como no caso apresentado, são apenas ocasionalmente envolvidas. Esta patologia apresenta elevada agressividade, rápida progressão e prognóstico reservado com sobrevida mediana de 12-24 meses. Atualmente não existe consenso na abordagem terapêutica devido à sua baixa incidência. Este caso realça a importância da abordagem multidisciplinar bem como o seguimento e registo desta entidade recentemente reclassificada (Revisão OMS 